\title{
Estrus and Estrus Behaviour and their Effect on Conception Rate in Crossbred Cows of Temperate Region of India
}

\author{
HK Bhattacharyya ${ }^{1 *}$, MR Fazili ${ }^{2}$ and AH Akand ${ }^{2}$ \\ ${ }^{1}$ Assam Agricultural University, India \\ ${ }^{2}$ Sher-e-Kashmir University of Agricultural Sciences and Technology, India
}

Submission: May 07, 2017; Published: October 02, 2017

*Corresponding author: Hiranya Kumar Bhattacharyya Senior Scientist and Head, Krishi Vigyan Kendra, Assam Agricultural University, P.O. Box. No. 24, P.O. Lahowal, Dibrugarh, India, Tel: 91-9419015186; Email: drhiranyabh@yahoo.co.in

Abstract

A total of 758 apparently healthy cattle represented in the nearby villages of the Faculty clinics and were also brought for insemination to the clinics was used to study behavioral and physical signs of estrus, diurnal variations in the occurrence of estrus and the effect of estrus intensity on conception rate (CR). Bellowing (92.67\%) and restlessness/aggressiveness (90.22\%) were found as most appreciable behavioral signs while, most appreciable physical signs of estrus recorded were tonicity of uterus (100\%), hyperemia of vulva (94.67\%) and relaxation of OS-cervix (89.17\%). Significantly lower number of animals (13.18\%) showed estrus in winter as compared to other seasons. Diurnal variation in the occurrence of estrus in different months and season of the year was found non-significant. Irrespective of the seasons maximum number of animals showed estrus, during 12 noon to $6 \mathrm{pm}$. Overall CR was recorded as $70.00 \%$ with the significantly highest being in animals showing good estrus (75.22\%) followed by moderate (60.26\%) and weakness (56.25\%) estrus respectively.

Keywords: Behavioural and physical estrus signs; Estrus intensity; Diurnal variations in estrus occurrence; Conception rate; Crossbred cows; Kashmir

\section{Introduction}

Artificial insemination (AI) is greatly dependant on efficient and successful heat detection that reduces extended periods of calving. To maintain an ideal 12-13 months calving interval, cows must be pregnant by 100 days after calving. As a guideline, $90 \%$ of the cows should have been observed in heat by 40-50 days after calving. It costs more than Rs. 300.00/- day to feed and house a dry cow. If the calving interval is 390 days instead of 365 days in a 100 cow herd, this added cost will approximately be $\$ 7500$ / year [1]. Inadequate estrus detection leads to missed breeding and low conception rate (CR). Improved estrus detection practices allows for heifers and cows to be bred artificially with genetically superior sire and also to achieve optimum calving interval. However, no estrus detection aid can ever completely substitute for the keen, conscientious observer. Therefore, close visual observation is very much required in efficient estrus detection [1]. Although there are anecdotal reports of improving CR of dairy cows, yet the actual outcome of such research has not been undertaken under field conditions particularly in India. The present study was thus undertaken to unravel different behavioural and physical signs of estrus and their effect on CR in crossbred cows of Kashmir, a temperate region of India.

\section{Materials and Methods}

A total of 758 apparently healthy cattle represented in the nearby villages of the Faculty clinics and were also brought for insemination to the clinics constituted the material of the present investigation. Bellowing, restlessness, aggressiveness, mounting, reduction in milk yield, frequent micturition, and reaction of the estrus cows shown when loaded AI gun (with semen straw) was placed in front of her nose for a few seconds, were recorded as behavioural signs of estrus. Behavioural signs were recorded from the history given by the owner and/ or from the continuous observation of these cows for about 30 minutes. Hyperaemia of vulva, swelling of vulva, quality of estrual discharge, tonicity of uterus, relaxation of os-cervix and presence or absence of palpable follicle were considered as physical signs of estrus and were recorded by physical and per-rectal examination of the reproductive tract. Estrus signs were recorded with respect to breed, parity and season. Season comprised of winter (December-February), spring (March-May), summer (June-August) and autumn (September-November). These twelve signs of estrus were assigned scores from 1 to 3 
(Table 1) in ascending order. Every animal was given a total score of 12-36 determined after adding individual values of various estrus signs. Depending upon the individual total scores, estrus was categorized as good, moderate and weak with a total score of 31-36, 19-30 and 12-18 for respective category. Insemination to the animals found in estrus, was carried out with frozen thawed semen having at least $50 \%$ post-thaw motility and 30 million spermatozoa per dose by a single gynaecologist using traditional thumb (am-pm) rule of insemination. The CR was determined with respect to type of estrus and was compared with Pearson's chi-square test [2].

Table 1: Estrus category.

\begin{tabular}{|c|c|c|c|c|}
\hline \multirow{2}{*}{\multicolumn{2}{|c|}{ Estrus Signs }} & \multicolumn{3}{|c|}{ Scores } \\
\hline & & 3 & 2 & 1 \\
\hline \multirow{6}{*}{$\begin{array}{l}\text { A. Behaviuoral signs of } \\
\text { estrus }\end{array}$} & 1. Bellowing & Continuous & Intermittent & Absent \\
\hline & $\begin{array}{l}\text { 2. Restlessness/ } \\
\text { aggressiveness }\end{array}$ & More & Less & Absent \\
\hline & $\begin{array}{l}\text { 3. Mounting and/ or } \\
\text { allowing mounting by } \\
\text { other animals }\end{array}$ & $\begin{array}{l}\text { Mounting and/ or allowing } \\
\text { mounting by other animals } \\
\text { with attempt to mount milkers } \\
\text { as well. }\end{array}$ & $\begin{array}{l}\text { Mounting and/or allowing } \\
\text { mounting by other animals }\end{array}$ & Absent \\
\hline & 4. Reduction in milk yield & $\geq 50 \%$ & $<50 \%$ & No reduction \\
\hline & 5. Frequent micturition & More & Less & Absent \\
\hline & 6. Reaction & Sniffing and trying & Sniffing and & No reaction \\
\hline \multirow{6}{*}{$\begin{array}{l}\text { B. Physical signs of } \\
\text { estrus }\end{array}$} & 1. Hyperaemia of vulva & Intense & Less intense & No hyperaemia \\
\hline & 2. Swelling of vulva & Intense & Less intense & No swelling \\
\hline & 3. Estrual discharge & Copious & Scanty & No discharge \\
\hline & 4. Tonicity of uterus & Pronounced & Moderate & Mild \\
\hline & 5. Relaxation of os-cervix & Completely dilated & Partially dilated & Un-dilated \\
\hline & $\begin{array}{l}\text { 6. Presence/absence of } \\
\text { palpable follicle }\end{array}$ & Large palpable follicle & Small palpable follicle & No palpable follicle \\
\hline \multicolumn{2}{|c|}{ Maximum total scores } & 36 & 24 & 12 \\
\hline
\end{tabular}

\section{Results and Discussion}

Out of 758 cattle presented for AI, 721 cows were found actually in estrus. Merely 5\% (4.88\%) animals were not found in estrus at the time of presentation of these animals. This reflects good literacy amongst the people of this locality regarding estrus detection of their cows.

\section{Behavioural Signs of Estrus}

Different behavioural signs of estrus and their occurrence have been depicted in (Table 2). In the present study, bellowing and restlessness / aggressiveness were found as most appreciable signs of estrus which were recorded in more than $90 \%$ cases (Table 2). Mounting and/ or allowing mounting by other animals were observed in about $80 \%$ animals, of which some $(34.44 \%)$ animals were so aggressive that they tried to mount milkers as well. Earlier reports indicated that bellowing, mounting and restlessness are most frequently observed signs of estrus [3]. [1] reported that standing heat or allowing to mount other cows when she stands is the most reliable heat sign; however, all riders are not necessarily in heat. Moreover, $5 \%$ of all pregnant cows and heifers also stands immobile when mounted by herdmates or by a bull. Reduction in milk yield and frequent micturition were observed in 81.91 and $72.16 \%$ cases respectively. Eighty percent estrous animals showed either sniffing and trying to lick (52\%) the AI gun or sniffing and trying to lick the gun with peculiar flehmen posture (32\%) when loaded AI gun with semen filled straw was placed in front of her nose. This might be due to receptive stage of the cow as she desires to mate.

Table 2: Behavioural signs of estrus and their occurrence with respect to breed, parity and season.

\begin{tabular}{|c|c|c|c|c|c|c|c|c|c|c|c|c|c|c|}
\hline \multirow{2}{*}{$\begin{array}{l}\text { Behavioural } \\
\text { Signs of Estrus }\end{array}$} & \multirow{2}{*}{$\begin{array}{l}\text { Type of } \\
\text { Estrus }\end{array}$} & \multicolumn{2}{|c|}{ Breed } & \multicolumn{6}{|c|}{ Parity } & \multicolumn{4}{|c|}{ Season } & \multirow{2}{*}{$\begin{array}{c}\text { Overall } \\
(\%)\end{array}$} \\
\hline & & $\mathrm{CB} / \mathrm{J}$ & $\begin{array}{l}\mathrm{CB} / \\
\mathrm{HF}\end{array}$ & Heifer & $1^{\text {st }}$ & $2^{\text {nd }}$ & $3^{\text {rd }}$ & $4^{\text {th }}$ & $\begin{array}{c}5^{\text {th }} \& \\
\text { above }\end{array}$ & Spring & summer & Autumnn & Winter & \\
\hline \multirow{3}{*}{$\begin{array}{l}\text { Bellowing } \\
(n=450)\end{array}$} & Continuous & 291 & 53 & 25 & 47 & 92 & 88 & 56 & 36 & 51 & 148 & 128 & 17 & $\begin{array}{c}344 \\
(76.44)\end{array}$ \\
\hline & Intermittent & 65 & 8 & 4 & 23 & 16 & 13 & 10 & 7 & 9 & 27 & 30 & 7 & $\begin{array}{c}73 \\
(16.22)\end{array}$ \\
\hline & Absent & 26 & 7 & 3 & 14 & 13 & 3 & 0 & 0 & 0 & 20 & 13 & 0 & $\begin{array}{c}33 \\
(7.33)\end{array}$ \\
\hline
\end{tabular}


Journal of Dairy and Veterinary Sciences

\begin{tabular}{|c|c|c|c|c|c|c|c|c|c|c|c|c|c|c|}
\hline \multirow{3}{*}{$\begin{array}{l}\text { Restlessness/ } \\
\text { aggressiveness } \\
\quad(n=450)\end{array}$} & $\begin{array}{c}\text { More } \\
\text { aggressive }\end{array}$ & 293 & 50 & 27 & 50 & 90 & 75 & 52 & 49 & 50 & 145 & 126 & 22 & $\begin{array}{c}343 \\
(76.22)\end{array}$ \\
\hline & $\begin{array}{c}\text { Less } \\
\text { aggressive }\end{array}$ & 58 & 5 & 5 & 20 & 15 & 10 & 11 & 2 & 10 & 23 & 28 & 2 & $\begin{array}{c}63 \\
(14.00)\end{array}$ \\
\hline & $\begin{array}{c}\text { Not } \\
\text { aggressive }\end{array}$ & 35 & 9 & 6 & 11 & 12 & 6 & 5 & 4 & 4 & 18 & 12 & 10 & $\begin{array}{c}44 \\
(9.78)\end{array}$ \\
\hline \multirow{3}{*}{$\begin{array}{l}\text { Mounting } \\
(\mathrm{n}=450)\end{array}$} & $\begin{array}{l}\text { Mounting } \\
\text { animals + } \\
\text { milkers as } \\
\quad \text { well }\end{array}$ & 139 & 16 & 16 & 23 & 29 & 36 & 26 & 25 & 21 & 45 & 62 & 27 & $\begin{array}{c}155 \\
(34.44)\end{array}$ \\
\hline & $\begin{array}{c}\text { Mounting } \\
\text { animal only }\end{array}$ & 188 & 19 & 23 & 49 & 32 & 38 & 26 & 39 & 27 & 82 & 61 & 37 & $\begin{array}{c}207 \\
(46.00) \\
\end{array}$ \\
\hline & Absent & 62 & 26 & 13 & 23 & 22 & 13 & 10 & 7 & 18 & 30 & 34 & 6 & $\begin{array}{c}88 \\
(19.56)\end{array}$ \\
\hline \multirow{3}{*}{$\begin{array}{l}\text { Reduction in } \\
\text { milk yield ( } \mathrm{n} \\
\quad=398)\end{array}$} & $\geq 50 \%$ & 45 & 13 & - & 11 & 17 & 10 & 7 & 13 & 6 & 39 & 10 & 3 & $\begin{array}{c}58 \\
(14.58)\end{array}$ \\
\hline & $<50 \%$ & 239 & 29 & - & 57 & 88 & 66 & 34 & 23 & 39 & 109 & 107 & 13 & $\begin{array}{c}268 \\
(67.33)\end{array}$ \\
\hline & No reduction & 62 & 10 & - & 34 & 10 & 18 & 3 & 7 & 5 & 32 & 32 & 3 & $\begin{array}{c}72 \\
(18.09)\end{array}$ \\
\hline \multirow{3}{*}{$\begin{array}{c}\text { Frequent } \\
\text { micturition } \\
(\mathrm{n}=450)\end{array}$} & $\begin{array}{c}\text { More } \\
\text { frequent }\end{array}$ & 142 & 16 & 11 & 24 & 49 & 38 & 25 & 11 & 15 & 73 & 65 & 5 & $\begin{array}{c}158 \\
(35.19)\end{array}$ \\
\hline & $\begin{array}{c}\text { Less } \\
\text { frequent }\end{array}$ & 148 & 18 & 13 & 26 & 52 & 37 & 24 & 14 & 17 & 76 & 66 & 7 & $\begin{array}{c}166 \\
(36.97)\end{array}$ \\
\hline & Absent & 114 & 11 & 25 & 12 & 26 & 25 & 16 & 21 & 35 & 62 & 23 & 5 & $\begin{array}{c}125 \\
(27.84)\end{array}$ \\
\hline \multirow{3}{*}{$\begin{array}{l}\text { Reaction } \\
(n=450)\end{array}$} & $\begin{array}{l}\text { Sniffing and } \\
\text { tried to lick } \\
\text { + flehmen }\end{array}$ & 117 & 27 & 20 & 27 & 37 & 32 & 10 & 18 & 18 & 51 & 71 & 4 & $\begin{array}{c}144 \\
(32.00)\end{array}$ \\
\hline & $\begin{array}{l}\text { Sniffing and } \\
\text { tried to lick }\end{array}$ & 212 & 22 & 15 & 41 & 62 & 54 & 41 & 21 & 36 & 59 & 134 & 5 & $\begin{array}{c}234 \\
(52.00)\end{array}$ \\
\hline & No reaction & 53 & 19 & 2 & 23 & 24 & 10 & 10 & 3 & 18 & 13 & 32 & 3 & $\begin{array}{c}72 \\
(16.00)\end{array}$ \\
\hline
\end{tabular}

\section{Physical Signs of Estrus}

Various physical signs of estrus and their occurrence have been shown in Table 3. The most appreciable physical signs of estrus recorded was tonicity of uterus (100\%) followed by hyperaemia of vulva (94.67\%) and relaxation of OS-cervix (89.17\%) [4] reported that uterine tonicity and relaxation of OScervix ate two important physical indicators for measuring estrus intensity in cows. Swelling of vulva was recorded in $88.89 \%$ cases. Vulva generally remains wrinkled or occasionally becomes smoother in non-estrous cows. Stringy clear mucus discharge can also be seen in the gutter or on the ground where an estrous cow had been resting (Keown and Kononoff, 2007). In this study, estrual discharge was recorded either copious (36.22\%) or scanty (14.89\%) in $63.78 \%$ cases together and in remaining $36.22 \%$ cases no discharge was found. Sometimes discharge came out during manipulation of reproductive tract by per-rectal examination. In most of the cases, scanty to no discharge was recorded in the animals which were examined after 14-16 hours from the onset of behaviuoral estrus; while as copious discharge was found in those animals, which were examined within 12 hours of estrus. This supports the earlier observation in cow [5] and goat [6] that estrual discharge is copious in early estrus and scanty or absent in late estrus. Follicle could be palpated only in $66.83 \%$ cases. By naked hand whether a follicle can be palpated or not that depends on the stage of estrus. In an animal where follicle is not palpated during early estrus, it may be palpated in the same animal which is examined during late estrus. In our study, follicle could be palpated in $81.91 \%$ (326/ 398) cases when another second examination was carried out 24 hours after the first. Moreover in delayed ovulators there is very less chance that follicle is palpated in early estrus.

Table 3: Physical signs of estrus and their occurrence with respect to breed, parity and season.

\begin{tabular}{|c|c|c|c|c|c|c|c|c|c|c|c|c|c|c|}
\hline \multirow{2}{*}{$\begin{array}{l}\text { Behavioural } \\
\text { Signs of } \\
\text { Estrus }\end{array}$} & \multirow{2}{*}{$\begin{array}{l}\text { Type of } \\
\text { Estrus }\end{array}$} & \multicolumn{2}{|c|}{ Breed } & \multicolumn{6}{|c|}{ Parity } & \multicolumn{4}{|c|}{ Season } & \multirow{2}{*}{$\begin{array}{c}\text { Overall } \\
(\%)\end{array}$} \\
\hline & & $\mathrm{CB} / \mathrm{J}$ & $\begin{array}{l}\mathrm{CB} / \\
\mathrm{HF}\end{array}$ & Heifer & $1^{\text {st }}$ & $2^{\text {nd }}$ & $3^{\text {rd }}$ & $4^{\text {th }}$ & $\begin{array}{c}5^{\text {th }} \& \\
\text { above }\end{array}$ & Spring & summer & Autumnn & Winter & \\
\hline $\begin{array}{c}\text { Hypearaemia } \\
\text { of vulva ( } \mathrm{n}= \\
450)\end{array}$ & Intense & 188 & 36 & 22 & 38 & 63 & 57 & 22 & 22 & 25 & 113 & 79 & 7 & $\begin{array}{c}224 \\
(49.78)\end{array}$ \\
\hline
\end{tabular}




\begin{tabular}{|c|c|c|c|c|c|c|c|c|c|c|c|c|c|c|}
\hline & Less intense & 170 & 32 & 16 & 60 & 44 & 44 & 22 & 16 & 25 & 95 & 66 & 16 & $\begin{array}{c}202 \\
(44.89)\end{array}$ \\
\hline & $\begin{array}{c}\text { No } \\
\text { hyperaemia }\end{array}$ & 21 & 3 & 3 & 0 & 9 & 6 & 3 & 3 & 3 & 3 & 18 & 0 & $24(5.33)$ \\
\hline \multirow{3}{*}{$\begin{array}{c}\text { Swelling of } \\
\text { vulva }(\mathrm{n}= \\
450)\end{array}$} & Intense & 148 & 25 & 19 & 50 & 50 & 35 & 13 & 6 & 13 & 63 & 75 & 22 & $\begin{array}{c}173 \\
(38.44)\end{array}$ \\
\hline & Less intense & 179 & 48 & 9 & 60 & 53 & 44 & 36 & 25 & 25 & 79 & 116 & 7 & $\begin{array}{c}227 \\
(50.44) \\
\end{array}$ \\
\hline & No swelling & 47 & 3 & 6 & 6 & 9 & 16 & 7 & 6 & 6 & 25 & 16 & 3 & $\begin{array}{c}50 \\
(11.11) \\
\end{array}$ \\
\hline $\begin{array}{c}\text { Quality } \\
\text { of estrual } \\
\text { discharge }\end{array}$ & Copious & 185 & 35 & 13 & 44 & 62 & 49 & 40 & 12 & 13 & 97 & 84 & 26 & $\begin{array}{c}220 \\
(48.89)\end{array}$ \\
\hline \multirow[t]{2}{*}{$(n=450)$} & Scanty & 45 & 22 & 12 & 2 & 40 & 4 & 9 & 0 & 18 & 31 & 9 & 9 & $\begin{array}{c}67 \\
(14.89) \\
\end{array}$ \\
\hline & $\begin{array}{c}\text { No } \\
\text { discharge }\end{array}$ & 145 & 18 & 22 & 26 & 22 & 53 & 22 & 18 & 40 & 88 & 31 & 44 & $\begin{array}{c}163 \\
(36.22)\end{array}$ \\
\hline \multirow{3}{*}{$\begin{array}{l}\text { Tonicity of } \\
\text { uterus (n } \\
=398 \text { ) }\end{array}$} & Pronounced & 227 & 47 & 15 & 49 & 64 & 67 & 47 & 32 & 35 & 116 & 101 & 22 & $\begin{array}{c}274 \\
(68.84) \\
\end{array}$ \\
\hline & Moderate & 96 & 18 & 7 & 42 & 35 & 22 & 3 & 5 & 15 & 54 & 27 & 18 & $\begin{array}{c}114 \\
(28.64)\end{array}$ \\
\hline & Mild & 5 & 5 & 5 & 0 & 5 & 0 & 0 & 0 & 0 & 3 & 5 & 2 & $10(2.51)$ \\
\hline \multirow{3}{*}{$\begin{array}{l}\text { Relaxation of } \\
\text { os-cervix (n } \\
\quad=397 \text { ) }\end{array}$} & $\begin{array}{c}\text { Completely } \\
\text { dilated }\end{array}$ & 243 & 40 & 18 & 53 & 68 & 71 & 38 & 35 & 25 & 129 & 96 & 33 & $\begin{array}{c}283 \\
(71.28)\end{array}$ \\
\hline & $\begin{array}{c}\text { Partially } \\
\text { dilated }\end{array}$ & 58 & 13 & 8 & 20 & 25 & 10 & 5 & 3 & 23 & 25 & 20 & 3 & $\begin{array}{c}71 \\
(17.88)\end{array}$ \\
\hline & Un-dilated & 30 & 13 & 8 & 15 & 11 & 2 & 2 & 5 & 3 & 20 & 15 & 5 & $\begin{array}{c}43 \\
(10.83)\end{array}$ \\
\hline \multirow{3}{*}{$\begin{array}{l}\text { Presence/ } \\
\text { absence of } \\
\text { follicle (n } \\
\quad=398 \text { ) }\end{array}$} & $\begin{array}{c}\text { Large } \\
\text { palpable } \\
\text { follicle }\end{array}$ & 78 & 12 & 13 & 25 & 21 & 13 & 13 & 5 & 7 & 29 & 25 & 29 & $\begin{array}{c}90 \\
(22.61)\end{array}$ \\
\hline & $\begin{array}{c}\text { Small } \\
\text { palpable } \\
\text { follicle }\end{array}$ & 154 & 22 & 11 & 34 & 42 & 38 & 30 & 21 & 18 & 54 & 90 & 14 & $\begin{array}{c}176 \\
(44.22)\end{array}$ \\
\hline & $\begin{array}{l}\text { No palpable } \\
\text { follicle }\end{array}$ & 111 & 21 & 20 & 29 & 19 & 32 & 12 & 20 & 4 & 57 & 57 & 14 & $\begin{array}{c}132 \\
(33.17)\end{array}$ \\
\hline
\end{tabular}

\section{Seasonal and Diurnal Variation of Estrus}

Significantly lower number of animals (13.18\%) showed estrus in winter as compared to other seasons. Although animals showing estrus in spring, summer and autumn season were varied, but statistically there was no significant difference amongst these three seasons (Table 4). Under agro-climatic condition of Kashmir cattle are stall-feed during winter and there is no supply of green fodder in this period leading to

Table 4: Effect of estrus intensity on CR in crossbred cows $(n=340)$.

\begin{tabular}{|c|c|c|c|c|}
\hline Estrus Intensity & No. of Animals & $\begin{array}{c}\text { No. of Animals } \\
\text { Conceived }\end{array}$ & CR (\%) & Chi-square Value \\
\hline Good estrus & 230 & 173 & 75.22 & \\
\hline Moderate estrus & 78 & 47 & 60.26 & 12.25 \\
\hline Weak estrus & 32 & 18 & 56.25 & \\
\hline Overall & 340 & 238 & 70 & \\
\end{tabular}

No drastic variation was observed in diurnal variation of estrus during different months and season of the year; however, irrespective of the seasons maximum number of reduced intake of vitamins and minerals. These factors could lead to occurrence of various reproductive disorders including anestrum [7]. Moreover extreme cold can directly affect reproductive capacity of animals [8]. Similar to the condition of summer infertility in buffaloes as observed in some hot parts of India during summer, reproductive capacity of animals also becomes lowered down in Kashmir during winter, as such an appropriate term for the condition 'winter infertility' may be used for the condition. 
opportunity for close watching of their livestock and there by efficient heat detection, which is not possible in rest of the time due to either reluctance at night time or non-availability of members in morning half of the day. So proper education to the farmers is necessary regarding close observation of their estrous cows and there by having ample opportunities for breeding of those cows. Earlier report indicated that estrus can be influenced by season of the year with more cows showing heat at night during hot weather and more heat at day during cold weather [1].

Table 5: Occurrence in the seasonal and diurnal variations of estrus $(n=721)$.

\begin{tabular}{|c|c|c|c|c|c|c|}
\hline Season & Months & 6 am-12 noon & 12 noon- 6 pm & 6 pm- 12 night & 12 night - 6 am & Overall \\
\hline \multirow{4}{*}{ Summer $(n=210)$} & June & 16 & 27 & 14 & 23 & 80 \\
\hline & July & 16 & 22 & 20 & 21 & 79 \\
\hline & August & 11 & 19 & 5 & 16 & 51 \\
\hline & Overall & $43(5.96 \%)$ & $68(9.43 \%)$ & $39(5.41 \%)$ & $60(8.32 \%)$ & $210(29.13 \%)$ \\
\hline \multirow{4}{*}{ Autumn $(\mathrm{n}=188)$} & September & 16 & 19 & 16 & 14 & 65 \\
\hline & October & 21 & 22 & 8 & 8 & 59 \\
\hline & November & 10 & 32 & 7 & 15 & 64 \\
\hline & Overall & $47(6.52 \%)$ & $73(10.12 \%)$ & $31(4.30 \%)$ & 37 (5.13\%) & $188(26.07 \%)$ \\
\hline \multirow{4}{*}{ Winter $(n=95)$} & December & 7 & 8 & 8 & 9 & 32 \\
\hline & January & 7 & 16 & 4 & 9 & 36 \\
\hline & February & 6 & 8 & 4 & 9 & 27 \\
\hline & Overall & $20(2.77 \%)$ & $32(4.44 \%)$ & $16(2.22 \%)$ & $27(3.74 \%)$ & $95(13.18 \%)$ \\
\hline \multirow{4}{*}{ Spring $(\mathrm{n}=228)$} & March & 14 & 18 & 11 & 21 & 64 \\
\hline & April & 15 & 23 & 13 & 17 & 68 \\
\hline & May & 15 & 35 & 21 & 25 & 96 \\
\hline & Overall & $44(6.10 \%)$ & $76(10.54 \%)$ & 45 (6.24\%) & $63(8.74 \%)$ & $228(31.62 \%)$ \\
\hline
\end{tabular}

\section{Effect of Estrus Intensity on CR}

Overall CR was recorded as $70.00 \%$ and was almost similar to the earlier findings in this locality [3]. This value was higher than one reported in Hariana breeds of India. However, overall CR as high as 82 to $91 \%$ was also reported in pure Holstein cows in Canada [9] . The cows included in our study belonged to uneducated rural farmers; so high CR observed in well organized farm is not expected here. Significantly higher CR (P: 0.017) was observed in animals showing good estrus (Table 5). Low CR was found in animals showing both moderate and weak estrus [10] recorded $0,14.74$ and $42.42 \%$ CR in animals showing weak, moderate and intense uterine tone respectively.

From the study it can be concluded that, bellowing (92.67\%), restlessness/aggressiveness (90.22\%) and mounting and/ or allowing mounting by other animals $(80.44 \%)$ were found as most appreciable behavioural signs of estrus. The most appreciable physical signs of estrus recorded were tonicity of uterus $(100 \%)$, hyperaemia of vulva $(94.67 \%)$ and relaxation of os-cervix (89.17\%). Significantly lower number of animals showed estrus during winter season as compared to other season of the year. Highest CR was recorded in the animals showing good estrus $(75.22 \%)$ as compared to either moderate $(60.26 \%)$ or weak $(56.25 \%)$ estrus.

\section{References}

1. Jeffrey FK, Paul JK (2007) Estrus (Heat) Detection Guidelines.
2. Snedecor GW, Cochran WG (1994) Statistical Methods $8^{\text {th }}$ edition, Iowa state University press, Iowa, USA pp 560.

3. Bhattacharyya HK, Fazili MR, Khan I, Bhat FA (2010) Fertility status of artificially inseminated crossbred cows of Kashmir valley. Asian Journal of Animal Sciences 4(2): 56-63.

4. Kumar A, Singh U, Inderjeet (2009) Fertility status of Hariana cows. Indian Vet J 86: 807-809.

5. Deshpande BR (1982) Oestrus and oestrous cycle In A Text book of Reproduction in Farm Animals (Theriogenology) by CR Sane, SN Luktuke, AS Kaikini, SB Kodagali, VB Hukeri, BR Deshpande, DP. Velhankar and VL Deopurkar 2nd Edition, Varghese Publishing House, Bombay India. pp 178.

6. Bhattacharyya HK, Goswami BK, Barua PM, Chakravarty P, Biswas RK (2000) Behavioural and physical signs of oestrus in Assam Local Goat. Indian J Anim Reprod 21(2): 126-127.

7. Wani NA, Buchoo BA, Khan MZ (1999) Treatment of longstanding anoestrus cows clinical study. SKUAST J Res. 1: 95-98.

8. Gordon I (2005) Reproductive Technologies in Farm Animals CABI Publishing London ISBN-10: $0851998623: 346$.

9. Dohoo IR (1983) The effects of calving to first service interval on reproductive performance in normal cows and cows with postpartal disease. Can Vet J 24(11): 343-346.

10. Gunasekaran M, Singh C, Gupta AK (2008) Effect of estrus behaviour on fertility in crossbred cattle. Indian Vet. J. 85: 159-163. 
This work is licensed under Creative Commons Attribution 4.0 Licens DOI: 10.19080/JDVS.2017.04.555628
Your next submission with Juniper Publishers will reach you the below assets

- Quality Editorial service

- Swift Peer Review

- Reprints availability

- E-prints Service

- Manuscript Podcast for convenient understanding

- Global attainment for your research

- Manuscript accessibility in different formats ( Pdf, E-pub, Full Text, Audio)

- Unceasing customer service

Track the below URL for one-step submission https://juniperpublishers.com/online-submission.php 